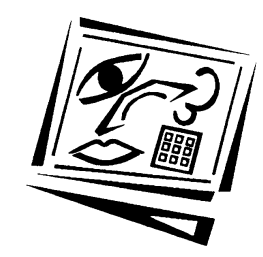

\title{
Information technology skills in the workplace: Implications for Bachelor of Arts degrees
}

\author{
Robyn Lawson and Christine de Matos \\ University of Western Sydney, Macarthur
}

\begin{abstract}
Changing work practices have increased demands for information technology (IT) skills within non-IT professions. Many employers want experience in desktop publishing, spreadsheets, and Internet skills, in addition to the 'traditional' areas of file management, word processing and databases. The demand for these skills was evident in our survey of Bachelor of Arts graduates with a Computing Studies major. However, whether workplace needs are being met by non-IT tertiary degrees, such as the BA, is open to investigation. Therefore this paper proposes a re-thinking of computer literacy in BA degrees to a two-tier competence. It also seeks to promote discussion and debate on the integration of advanced IT skills into higher education, with a particular emphasis on BA degrees. Barriers to effective IT integration include technical issues, lack of training and incentives for staff, students' unpredictable IT skill level on entry to tertiary education, and their access to resources. The discussion is limited to administrative and teaching careers, as these were the dominant non-IT career choices of BA graduates in our survey. However, the issues related to the integration of IT across discipline areas in higher education to satisfy the needs of the workplace are quite generic. If the IT skills demanded by employers are to be supplied, then a higher priority needs to be placed on IT skills of academic staff, and on integrating advanced IT skills across and within the teaching and learning framework for students in tertiary education.
\end{abstract}

\section{Introduction}

Information technology (IT) has become an integral tool in the workplace, necessitating a level of IT skill for effective participation in most careers. This places pressure on tertiary education to provide graduates with an appropriate level of computer literacy. While the need for students to become computer literate is not contentious (Reid, 1997; Eisenberg and Johnson, 1996) the skills that should be included for particular groups of students is debatable. Today computer literacy has moved beyond basic 
word processing and file management, to desktop publishing, knowledge of spreadsheets, and Internet skills. In addition, the ability to move between packages is now in demand, to the point where computer literacy today tends to mean generic or transferable skills (Mason, 1995), which changes the focus from the technical issues of hardware (ie what platform) and software (ie what word processing package), to a more skill-based approach to computer literacy. Another aspect is the unpredictable nature of students' computer literacy on entry to tertiary education, and the incorrect premise by some academic staff that they are already computer literate (Reid, 1997). As most careers require some level of computer literacy, perhaps we have reached the stage where computer literacy takes on a more complex meaning. Computer literacy applies not only to tertiary education graduates, but also, to academic staff.

The development of networks, new ways of teaching with computers, and the emergence of the Internet are topical issues. Some academic staff are motivated by the possibilities they offer for the flexible delivery of university courses. Others are resisting the pressure to adapt in a time where universities are changing as places of traditional learning. One of the challenges is the question of whether a different type of academic staff member is needed (Collens, 1993); one who, regardless of discipline, is computer literate and able to integrate IT into their teaching to complement other teaching and learning experiences.

For academic staff to be able to integrate IT into their teaching, computers must be meaningful to them on a personal level (Cheung, 1996). Many academic staff use computers for preparation of teaching materials, research papers, correspondence and collating marks. Some researchers believe that this use of computers on a personal and management level is the first stage of a two-stage model, and is essential before moving to the second stage where computers can be integrated into teaching (Snyder, 1993, cited in Overbaugh, 1993). IT has no respect for academic boundaries, and has penetrated all disciplines and become a focus for changing modes of subject delivery within universities (Yetton, 1997; Ward, 1994). It is important then for non-IT disciplines within a BA degree - a traditional non-IT domain - to examine whether IT can effectively be incorporated into its teaching programs, not at the expense of content or teaching and learning strategies, but to enhance them.

The aims of this paper are: to investigate the trend in demands for IT skills in the workplace; to examine experiences of BA graduates in using IT skills gained during the degree; and from this to explore implications for BA degrees, both within the framework of teaching and learning, and for academic staff. 


\section{Survey of BA graduates}

To investigate IT skills currently being utilised in the workplace, a study of graduates with a BA degree from the University of Western Sydney, Macarthur, was undertaken. This BA degree includes the option of a major in Computing Studies. Over recent years Computing and Information System sequences have become a feature of this type of degree (UAC Guide, 1998). At UWS, Macarthur, BA students have a combination of majors. The choice is made from the following: Asian Studies, Communication, Computing Studies, Creative Writing, History, Literature, Politics, Psychology, Social Anthropology and Sociology. This survey covered four years of BA graduates with a Computing Studies major. The most common other majors for this group of graduates was Psychology or Communication.

Between 1994 and 1997 seventy-three BA graduates from UWS, Macarthur had undertaken a Computing Studies major. Thirty-one graduates $(42.5 \%)$ responded to the survey. The aims of the survey were to track graduates' career paths, further study undertaken and to determine the perceived value of undertaking a Computing Studies sequence as part of a BA program. Table 1 sets out the area of work of graduates and their job classifications.

\begin{tabular}{|l|c|l|}
\hline Area of work & $\%$ & Job classifications \\
\hline IT Industry & 38.7 & $\begin{array}{l}\text { Programmer } \\
\text { Analyst/Programmer } \\
\text { Systems Analyst } \\
\text { Technical Support Officer } \\
\text { User Support Officer } \\
\text { Customer Support }\end{array}$ \\
\hline Administration & 16.0 & $\begin{array}{l}\text { Administrative Officer } \\
\text { Office Manager } \\
\text { Credit Card Administrator } \\
\text { Human Resources Officer } \\
\text { Warehouse Operations }\end{array}$ \\
\hline Teaching & 10.0 & $\begin{array}{l}\text { Computing Studies Teacher } \\
\text { Teacher in non-computing areas }\end{array}$ \\
\hline Other & 35.0 & $\begin{array}{l}\text { Areas include: Police, Aviation, Health, Marketing, } \\
\text { Welfare, Retail, Travel and Research }\end{array}$ \\
\hline
\end{tabular}

Table 1: Career paths of BA graduates with Computing Studies major $(n=31)$ 
When asked why they chose to undertake a Computing Studies major, this group of graduates made the following responses:

\begin{tabular}{|l|c|c|}
\hline $\begin{array}{l}\text { Factors contributing to decision to follow a } \\
\text { Computing Studies major }\end{array}$ & $\begin{array}{c}\text { No. of } \\
\text { responses }\end{array}$ & $\%$ \\
\hline Enhance my ability to obtain work & 21 & $68 \%$ \\
\hline Increased use of computers in society & 20 & $64 \%$ \\
\hline Personal interest in computers & 20 & $64 \%$ \\
\hline Complement other studies & 9 & $29 \%$ \\
\hline Computer subjects in first year * & 7 & $23 \%$ \\
\hline
\end{tabular}

Table 2: Factors contributing to Computing Studies major $(\mathrm{n}=31)$

* The UWS Macarthur BA requires all students to achieve a basic level of computer competency by successfully completing the subject, Introduction to Computers.

Interestingly, $68 \%$ believed that choosing a major in Computing Studies would enhance their ability to obtain work. Judging by the diversity of careers it could be suggested that regardless of work area, proficiency in IT is an attractive skill to prospective employers, and students are aware of this. Use of computers in society was considered by $64 \%$ of respondents to be a contributing factor to choosing a Computing Studies major, as was their own personal interest in computers. These latter comments demonstrate student awareness of computer literacy as an important part of effective functioning in contemporary society, inside and outside the workplace. The $29 \%$ of students who indicated they undertook a Computing Studies major to complement other subjects may suggest that this need is not being met within the specific discipline areas.

In addition, $80 \%$ indicated that it had been the right decision to undertake a Computing Studies major. Comments included:

"We can't live without computer knowledge these days"

(Administrator, 1994 graduate)

"It helped me gain employment and was a good basis as the start of my career"

(Analyst/Programmer, 1995 graduate)

"Department of School Education likes to employ computer literate teachers - our studies are quite diverse"

(Teacher, 1996 graduate)

"I've developed an unmatched passion for computers"

(Police Officer, 1997 graduate) 
When evaluating the usefulness of undertaking the Computing Studies sequence, $80.6 \%$ indicated that it enhanced their ability to apply for advertised positions, and was a valuable learning experience. A majority agreed $(66.6 \%)$ that they had been able to apply the skills and knowledge gained to their career.

Further study since completing the BA included Masters degrees (16.7\%), teaching qualifications (33.3\%) as well as other training courses relevant to their careers. The reason for undertaking further study was job requirement $(33.3 \%)$, personal interest $(50.0 \%)$ and better qualifications $(16.7 \%)$. To enhance their job satisfaction and career prospects $53.3 \%$ indicated that they intended to pursue further study. Is part of the reason for this intention related to the rapidly changing nature of IT in the workplace and the need to keep up to date?

\section{Confirming the results of the survey}

The dominant non-IT career choices from the survey were in teaching and administrative areas. Therefore, the remainder of this paper focuses on these areas, although the issues discussed are of wider significance and interest. References to the teaching profession relate to those students who complete a postgraduate pre-service teaching degree or diploma after undertaking a BA as their undergraduate degree. To address the needs of full undergraduate pre-service teacher training is beyond the scope of this paper.

When considering the issue of computer literacy for administrators, it seems predictions that IT would deskill work have proved false. On the contrary, administrative workers who use advanced IT skills have reported increased job satisfaction (Long, 1993). Managers now type their own reports, and administrative assistants are becoming desktop publishers, data analysts and researchers. Interestingly, employers have become more discerning, valuing not just a general ability to use a computer, but valuing specific and more advanced skills (Hawke, 1998). For example, production of a brochure or a web page can be viewed as two inter-related tasks: content and design. Both tasks can be performed using a computer, but the design task requires advanced IT skills.

When considering the issue of computer literacy for teachers, the question of where to start provokes debate. Should the analysis start in the schools, before students reach university? Or should it start at university, before teacher trainees are released into the school system? The importance of IT is incorporated into the curriculum and a move towards integrating IT into 
teaching is occurring in Australia, but only in some parts of the school system. The NSW Department of Education and Training (DET) have technology advisers, and some in-service training, ie the Technology in Learning and Teaching (TILT) program, but teachers still need to rely on their own resources to acquire the necessary skills to feel comfortable in integrating IT into their teaching (Jackson, 1998). If the school system requires that all teachers should be computer literate, and be able to integrate IT into their teaching, then pre-service education needs to have IT fully integrated into teacher education programs, and target the integration of IT into classrooms (Downes, Perry and Sherwood, 1995).

\section{What are the current it skills needed in the workplace?}

To ascertain the current need for IT skills in administrative and teaching careers a number of paths were explored. An examination of the employment sections of Sydney's newspapers, the Sydney Morning Herald and The Australian, was undertaken over two separate one-month blocks in 1998. These results were then compared with a number of Internet sites related to employment in Australia. The employment section of the Sydney Morning Herald in the same two separate one-month blocks in 1995 and 1992 was also undertaken. Further, the NSW DET was canvassed to build a profile of relevant IT skills. This allowed a comparison to identify trends in IT skills over a six-year period.

\section{IT skills for employment in administration}

Employment in Administration primarily included administrative officers and administrative assistants. Skills demanded for administrative officers included desktop publishing, spreadsheets, database, knowledge of information systems, and interest in the new technologies. The most requested IT skills for administrative assistants were general computer literacy and reasonable typing skills (around $40 \mathrm{wpm}$ ). Some employers also asked for expertise in software applications such as presentations and database. There were some requests for more specialised skills including familiarity with accounting software (eg MYOB), or html/web page design skills. 


\section{IT skills in the teaching profession}

Despite many barriers and confusion about the role of information technology in schools, the NSW DET has identified IT skills as desirable for teachers. These can be divided into two types of IT skills, ie those for Computing Studies teachers (secondary) and general skills required by all teachers.

\section{IT skills for Computing Studies teachers}

A Computing Studies teacher needs to develop a wide range of IT skills, as demanded by the syllabus. These are related to general application skills (word processing, spreadsheets, database, graphics), problem solving (algorithms, programming), more specific IT areas (data communications, database design, artificial intelligence and expert systems), recent technologies (Internet, multimedia) and issues concerning computers in the workplace and in society.

In recent years, due to a shortage of Computing teachers, Computing Studies has been taught by teachers from other discipline areas, without appropriate qualifications. However, as from 1998 graduates are required to have a major Computing sequence to be employed by the NSW Department of Education and Training (Manuel, 1999).

\section{General IT skills for all teachers}

It is also desirable that teachers entering K-6 and other non-IT related secondary teaching have IT skills. These skills include experience using common applications (word processing, spreadsheets, presentation software, and graphics), file management and more recent technologies (Internet, multimedia). Table 4 contains more details. However, experience using a package does not translate directly into the ability to integrate IT into the classroom - the latter is a task in itself and is best addressed through pre-service and in-service teacher training.

\section{Has the desired level of it skills increased over time?}

An examination of skills required for employment in Administration and Teaching show a progressive increase in the level of IT skills from 1992 to 1998. In 1992 basic levels were evident for careers in Administration. Table 3 shows required IT skills for advertised positions in Administration for 1992, 1995 and 1998 ranked according to level of demand. 
Administration

\begin{tabular}{|l|l|l|}
\hline \multicolumn{1}{|c|}{1998} & \multicolumn{1}{c|}{1995} & \multicolumn{1}{c|}{1992} \\
\hline interest in new technologies & word processing & word processing \\
\hline desktop publishing & spreadsheets & spreadsheets \\
\hline spreadsheets & desktop publishing & $\begin{array}{l}\text { knowledge of } \\
\text { computer systems }\end{array}$ \\
\hline database & $\begin{array}{l}\text { knowledge of computer } \\
\text { systems }\end{array}$ & \\
\hline presentations & presentations & \\
\hline knowledge of information systems & database & \\
\hline html/Web page design skills & & \\
\hline $\begin{array}{l}\text { specialised skills, eg accounting } \\
\text { software }\end{array}$ & & \\
\hline
\end{tabular}

Table 3: Computer skills demanded by employers in administrative careers

In 1992 advertisements for administrative positions, revealed that a higher priority was placed on organisational and communication skills, with computer skills in word processing, spreadsheets and knowledge of computer systems lower in priority, or not mentioned. By 1995 more emphasis was placed on computer skills in general, with skills in desktop publishing, presentations and database appearing in some job advertisements. In 1998 interest in new technologies, Internet skills such as web page design and more specialised software skills emerged. This trend would indicate a dependence on computers, and that advanced IT skills are highly valued for administrative careers.

The progressive changes in demand for IT skills in the teaching profession is not quite as clear to chart. In recent times, the use of IT in teaching can best be described as ad hoc, and IT skills gained by teachers were primarily through self-motivation (Dailhou, 1999; Harriman, 1999). However, DET has introduced a number of initiatives over the last few years, including provision of hardware resources, Internet access, curriculum support materials, technology advisers and in-service teacher training, under the Government's Computers in Schools Policy (DET, 1997). Today we are on more confident ground with a definition of computer proficiency for beginning teachers developed in 1997 by the Ministerial Advisory Council on the Quality of Teaching (MACQT). The table below lists the levels of computer proficiency teaching graduates will now have to meet. Universities are expected to implement programs to achieve the recommended levels by the year 2000, and employment agencies are being 
encouraged to use this set of competencies as criteria for employment as teachers in NSW (MACQT, 1997).

\begin{tabular}{|l|l|}
\hline Basic Operations & $\begin{array}{l}\text { Understanding functions \& components; Use of basic } \\
\text { applications; Information retrieval from CD-ROMs \& } \\
\text { commercial products; Graphics and art work; Simple Desktop } \\
\text { Publishing; Drill and Practice activities }\end{array}$ \\
\hline $\begin{array}{l}\text { Information } \\
\text { Technology }\end{array}$ & $\begin{array}{l}\text { Using Multimedia presentations; Using interactive } \\
\text { presentations; Use of Internet and email }\end{array}$ \\
\hline $\begin{array}{l}\text { Software } \\
\text { Evaluation }\end{array}$ & $\begin{array}{l}\text { Generation of lesson plans; Match applications to curriculum } \\
\text { content; Evaluate software for educational purposes; Structure } \\
\text { programs / lessons to incorporate useful computer activities; } \\
\text { Evaluate student learning for computer-based activities }\end{array}$ \\
\hline Pedagogical Issues & $\begin{array}{l}\text { Understanding how IT enhances student learning; Creation of } \\
\text { self-regulated learning environments; Management of } \\
\text { classroom environment and school resources; Ability to use } \\
\text { computers for administrative and student reporting purposes }\end{array}$ \\
\hline Values and Ethics & $\begin{array}{l}\text { Recognition of plagiarism; Understanding copyright, } \\
\text { censorship \& privacy; Appropriate access to \& verification of } \\
\text { Internet information; Interpersonal skills in teaching } \\
\text { environment where colleagues have wide range of IT skills }\end{array}$ \\
\hline
\end{tabular}

Table 4: Adapted from the MACQT Report on Computer Proficiency for Teachers (1997)

The trend since 1992 is towards more sophisticated IT skills for careers in Administration which reflects increased use of IT, and is in line with the emergence of new technologies. These definitely include skills that could be met within the BA structure. In Teaching, while pedagogical issues are the domain of pre- and in-service teaching courses, most of those under Basic Operations and Information Technology (see Table 4) are candidates for IT skills within a BA degree.

\section{Implications for Bachelor of Arts degrees}

The findings above confirm that IT skills beyond the basic level are being demanded by employers in administrative and teaching professions. To confirm this, the graduate survey indicates that these graduates found the computing skills gained as a major part of their studies were beneficial in attaining employment in these areas. What then are the implications for BA degrees if they wish to meet these demands? Have they been able to meet these demands so far? 
The introduction of computer competencies into university degrees has seen students develop basic skills. However, in some degrees the use of IT for teaching and learning is not considered unless the individual lecturer has an interest in using computers (Downes, Perry and Sherwood, 1995). A number of interesting innovations have emerged in universities that move towards integrating IT into teaching. Not surprisingly, a number of these innovations have come from traditional Computing, as well as from lecturers who have an interest in computing. The next step involves encouraging and supporting all academic staff to acquire the necessary IT skills to enable them to firstly, effectively use computers on a personal and management level, and secondly, to participate in flexible delivery initiatives that include the integration of IT within their discipline.

Whether the IT skills demanded by employers can be supplied within the framework of tertiary education will depend on how tertiary education responds to integrating higher level IT skills, and how well computer literacy is managed. We have divided the broad needs of commitment to IT in tertiary education, with particular emphasis on the BA style of degree, as follows:

\section{Preparation for working in certain IT related professions}

Universities need to offer training for students to move into IT related areas. This would involve two main areas: technical expertise and management expertise. Technical training would obviously come from many of the Computer Science degrees already in existence. However, those following a career in IT management or user support need not study Computer Science. They need some technical expertise, but the ability of a BA degree to combine technical experience with another major, such as Communication or Psychology, would give BA graduates a distinct advantage over Computer Science graduates in IT management areas. Universities need to make sure they are offering students this choice to meet the demands of industry. The following comment from a 1995 graduate currently working as a Technical Support Officer illustrates this point:

"...BA graduates have a lot more to offer to industry than our Computer Science colleagues..."

\section{Preparation for administrative and other non-IT areas}

Regardless of the discipline studied or career choice, students need to graduate with IT skills. This may include basic skills subjects; followed by advanced discipline-specific IT subjects; and the integration of advanced IT skills across and within teaching and learning frameworks throughout the BA degree structure. 


\section{Preparation for the teaching profession}

In the specialised area of pre-service teacher training, it is even more imperative to integrate IT across the teaching and learning curriculum. In order to meet the demands of government, parents and society in general, a computer literate teaching profession is required to produce computer literate students.

To judge pre-service teaching Bachelor degrees is, as stated earlier, beyond the scope of this paper. However, there are special implications for nonteaching undergraduate degrees. As many students enter the teaching profession via a BA (or similar undergraduate degree) followed by a one or two year postgraduate teaching degree, it is desirable that the undergraduate degree should provide adequate training in IT. This would allow the graduate teaching degree/diploma to concentrate on the delivery of IT to support curriculum objectives and outcomes and on other pedagogical issues rather than on basic IT skills. IT needs for BA graduates entering postgraduate pre-service education could be met through point 2 above.

In the case of BA students who wish to specialise as Computer Studies teachers, a major within the BA structure, as outlined in Point 1 above, would be a desirable option. If this is encouraged, it may help the integration of IT within secondary education by breaking the perceived nexus of Maths/Computing or Science/Computing method combinations that typically come out of Science undergraduate degrees. Through a BA, Computing Studies could be combined with other disciplines leading to greater dynamism within Computing Studies, and blurring the traditional barriers between departments thus aiding integration of IT across the curriculum.

To summarise the above, we have identified three separate dimensions within the tertiary education sector where IT skills can be integrated:

- advanced technical skills for IT professionals

- IT across the discipline structure:

- two-tier computer literacy: basic and advanced skills

- integration of IT in teaching and learning

- IT skills for entry to postgraduate teaching degrees 


\section{Re-thinking computer literacy}

Trends in demands for increased IT skills in administration and teaching would infer that it is time to consider computer literacy as a two-tier competence for students. The first tier consists of basic skills of word processing, file management and electronic communication. The second tier encourages more advanced skills such as desktop publishing, Internet and a range of other software, eg spreadsheets, database and presentations. Academic staff would also need discipline-related skills to demonstrate IT integration within their own teaching programs.

The needs of IT professionals, the first dimension above, can best be regarded as part of specialised Computer Science/Engineering degrees (technical) or as a major sequence of a BA degree (IT management). Of special relevance to this paper is the second and third dimension. To provide both generic and specialised advanced IT skills, computer-based teaching and learning experiences need to be incorporated across discipline areas in BA degrees. The application of skills in the second-tier of computer literacy are best experienced as part of a particular discipline area, or as specialised computing subjects. For example, the uses of technology in historical research are best learnt as part of Humanities subjects, or in the social sciences as part of a social science degree, etc. This is an extension to the current generic computing subjects, which are usually limited to basic computing skill acquisition - ie to the first tier of computer literacy. Introductory computing subjects now need follow-on discipline-specific subjects (the second-tier), which offer more advanced computer skills.

While universities in Australia assume a level of computer literacy for graduates, the level of competence required is defined in general terms, eg familiarity with terminology and strategies associated with computers (Reid, 1997). Some universities offer separate introductory computing subjects, while others have integrated computing with discipline specific subjects. Perhaps both these approaches are feasible if scheduled sequentially, as a two-tier program of computer literacy. Further research could include a study of computer literacy programs at overseas universities. Also, BA graduates without a Computing Studies major could be surveyed to ascertain and compare their experiences with BA graduates with a Computing Studies major. 


\section{Barriers to effective IT integration}

Some barriers to effective integration of IT in university programs may appear obvious, while others may appear to be more subtle. These are listed below, but are by no means exhaustive:

1. Not all lecture theatres are set up for IT, and the use of computers has been assigned to computer labs, which are usually heavily booked, and considered for the sole use of practical 'hand-on' classes, particularly by Computer Centre administrators. The ad hoc booking for special classes during the semester, or for intensive week-long workshops is viewed by Computer Centre administrators as a hindrance, particularly for classes that are not "real computing" (Nanlohy, 1995).

2. In addition to the hardware and software, adequate instructional materials to complement course content are needed, as is trained support staff for maintenance of the resources.

3. Some academic staff have completed their own degrees before IT was introduced and consequently lack the requisite skills in the use of IT. Available training is not tailored to the needs of particular discipline areas. Faculty members who use IT usually have some computing background, or have pursued knowledge and professional development in their own time. In non-computing disciplines, some academic staff are as uncomfortable with IT as their students (or perhaps more), and pretend no interest in computers to avoid the need to use them.

4. Lack of incentive is another barrier. Release time, promotion and support is provided on research and publication efforts, not on time or energy spent on improving teaching methods by integrating IT.

5. Students have an unpredictable IT skill level. A definition of an appropriate level of computer competency needs to be developed by the Faculty/University and appropriate programs put in place to ensure this level. This would allow lecturers who do wish to incorporate IT into their subjects to assume a certain level of competence. For instance, lecturers may want to assume knowledge of the Internet rather than having to spend time teaching students how to use it. 
6. Access for students to appropriate computing facilities to complete ITrelated tasks cannot be assured. Home access cannot be assumed, and computing labs often have limited availability due to classes, and / or limited resources.

\section{Conclusion}

The demand for IT skills in the workplace now goes beyond the basic level of competency, ie the first tier. The survey of BA graduates indicates that graduates need IT skills to work in non-IT professions such as administration and teaching. Outside the IT industry, graduates could provide expertise to organisations without designated IT staff. Pre-service teaching graduates should be able to incorporate the use of computers into their teaching regardless of discipline specialisation.

Due to factors affecting the integration of IT at primary and secondary levels, students are entering the tertiary system with levels of IT skills and awareness which are unpredictable, and range from non-existent to proficient (Tapper, 1997). This puts pressure on universities to develop and fund courses to provide basic IT skills across multiple non-IT disciplines. If this is not done, universities have to face the question of whether they are doing enough to prepare today's students for tomorrow's encounters with the rapidly evolving world of IT in the workplace. Jevons (1984) believes "it is not education's job merely to adapt to technological change" (p 95). He claims that education should be more active, and help shape change, by providing a range of suitable IT skills. Certainly, incentives for staff such as release time, promotion criteria and support for energy spent on integrating IT could be a starting point. This would, perhaps, result in reaching full integration more quickly.

The challenge facing academic staff in tertiary education is very similar to the challenge facing teachers in schools. Academic staff must first feel comfortable using computers themselves, and then take on the task of integrating IT into their teaching, as suggested by Cheung (1996) and Snyder (cited in Overbaugh, 1993). Staff teaching in computing disciplines are ideally placed to integrate IT into teaching, and, this is evident, despite lack of resources. Partnerships with staff teaching in non-computing disciplines are now being suggested as a way of moving to full integration of IT into teaching and learning frameworks. This, along with establishment of a policy at university level, may alleviate the current ad hoc approach to acquiring IT skills, and integrating IT into teaching and learning. 
The incorporation of computer literacy into tertiary education is imperative, as is the acknowledgment of tiers within the meaning of computer literacy for students. A computer-literate tertiary-educated workforce and teaching profession will produce computer-literate children, as well as providing workers with the necessary IT skills. If positive experiences with IT begin in the primary and secondary years, computing could become an essential skill to complement those in reading, writing and numeracy. In fact, perhaps it is time to reject the idea that IT is purely a technical skill, and realise it fully as a form of literacy in the 'traditional' sense (as with reading, writing and numeracy) that is required to function effectively in the broader context of society. In the long term, integration across the primary and secondary curriculum could create a 'flow down' effect in the education system. This may mean the day will come when there will be an expectation that students (and staff) entering tertiary education will already have these skills, and there will be a requirement only for remedial courses in much the same way as there currently exists for reading, writing and numeracy. This will allow universities to concentrate on teaching advanced IT skills, ie the secondtier, and on the integration and delivery of IT across the discipline structure.

This, of course, is not a scenario for the near future. In the meantime, the main challenge is to overcome deficiencies in IT skills of academic staff and students, as well as in access to resources. Since the acquisition of IT skills is beneficial to industry (as it saves money spent on training or retraining hired staff) one answer to be investigated and pursued may be in more extensive partnerships between tertiary institutions and industry. Due to the dynamic nature of IT, there is a need for continuous dialogue between tertiary institutions and industry to meet the constantly changing IT needs of employers.

Certainly for tertiary education to fully meet the needs of students and the workplace, IT skills beyond the basic level need to be incorporated into courses to ensure that graduates can embrace the emerging technologies facing society, both today, and in the future.

\section{Bibliography}

Australian Job Search. http: / / jobsearch.dewrsb.gov.au/occ_list.asp [viewed 12 Dec 1998]

Byron Employment Australia. http: / / employment.byron.com.au/ [viewed 12 Dec 1998; verified 11 Jul 2000] 
Cheung, W. (1996). Understanding pre-service teachers' background in using computer technology. Australian Association for Research in Education Conference. http:/ / www.swin.edu.au/aare/conf96/CHEUW96.130 [verified $11 \mathrm{Jul} 2000]$

Collens, L. (1993). The future of engineering and science education: the confidence and courage to be ambitious. Vital Speeches of the Day, September, 368-372.

Dailhou, P. (1999). Former President, NSW Computer Education Group, Email correspondence 2 Apr 1999.

Department of Education and Training (1997). Preparing Students, Teachers and Schools for the New Millennium: A Report on Information Technology in New South Wales Schools. http:/ / www.dse.nsw.edu.au/stand.cgi/staff/F6.0/index.htm [viewed 17 Apr 1999; verified 11 Jul 2000]

Downes, T., Perry, R. and Sherwood, C. (1995). IT in education and teacher education in Australia. Journal of Computer Assisted Learning, April, 23-34.

Eisenberg, M. and Johnson, D. (1996). Computer Skills for Information ProblemSolving: Learning and Teaching Technology in Context, ERIC Digest. http: / / www.ed.gov/ databases / ERIC_Digest/ed392463.html [viewed 13 Nov 1998]

Employment Opportunities Australia. http:/ / careermosaic.jobs.com.au/jobs.html [viewed 12 Dec 1998; verified 11 Jul 2000]

Harriman, S. (1999). Curriculum Consultant, Learning Technology, NSW Department Education and Training, Interview 6 May 1999.

Hawke, A. (1998). Gender differences in wage returns to computer skills in Australia. Prometheus, 16(10), 5-12.

Jackson, N. (1998). A class act? Information Age, February, pp 22-23.

Jevons, F. (1984). Universities: getting it together. Technological Change: Impact of Information Technology 1984. Department of Science and Technology and the Australian Computer Society Inc, pp95-106.

Kay, R. H. (1993). A practical research tool for assessing ability to use computers: The computer ability survey. Journal of Research on Computing in Education, 26(1), 16-27.

Long, R. (1993). The impact of new office information technology on job quality of female and male employees. Human Relations, 46(8), 939-961.

Manuel, J. (1999). Bachelor of Teaching (Secondary) Coordinator, Faculty of Education and Languages, University of Western Sydney, Macarthur.

Mason, J. (1995). Issues for teacher education. Proceedings, AusWeb95. http:/ / www.scu.edu.au/sponsored/ausweb/ausweb95/papers/education2/ mason/ [verified 11 Jul 2000] 
Ministerial Advisory Council on the Quality of Teaching (MACQT) (1997). Report on Computer Proficiency for Teachers. http: / / www.det.nsw.edu.au/macqt/ [viewed 17 April 1999; verified 11 Jul 2000]

Nanlohy, P. (1995). Infiltrating educational technology. Conference on Educational Technology, University of Western Sydney, Nepean, 20 April 1995.

Overbaugh, R. C. (1993). Critical elements of computer literacy for teachers. Paper presented at the Annual Meeting of the National Society of Educators and Scholars, March, 1993.

Reid, I. (1997). Computer literacy in higher education. Proceedings, ASCILITE97 Conference.

http: / / www.curtin.edu.au / conference/ ASCILITE97/ papers / Reid/Reid.html [viewed 3 Dec 1997; verified 11 Jul 2000]

Sydney Morning Herald. Employment Section, June and December, 1998, 1995 and 1992.

Tapper, J. (1997). Integrating online literacy into undergraduate education: A case study. Higher Education Research and Development, 16(1), 25-40.

The Age. http: / / www.theage.com.au/jobs / [8 June 1998, 8 Dec 1998; verified at http:/ / www.mycareer.com.au/fulltime/index.html 11 Jul 2000].

The Australian. Employment Section, June and December, 1998.

Universities Admission Centre (NSW and ACT) Pty Ltd (1998). UAC Guide. Mulgrave, Vic: McPherson's Printing Group

Ward, D. (1994). Technology and the changing boundaries of higher education. EDUCOM Review, 29(1), 23-27. http: / / www.educause.edu / pub / er / review / reviewArticles / 29123.html [verified 11 Jul 2000]

Wilmott, V. (1999). Senior Recruitment Officer, NSW Department of Education and Training, Interview 20 April 1999.

Yetton, P. (1997). Managing the Introduction of Technology in the Delivery and Administration of Higher Education. Canberra : Australian Government Publishing Service.

Robyn Lawson, Lecturer in Computing, Faculty of Arts and Social Sciences, University of Western Sydney Macarthur, Campbelltown, NSW 2560.

r.lawson@uws.edu.au

Christine de Matos, Postgraduate Student, Faculty of Arts and Social Sciences, University of Western Sydney Macarthur, Campbelltown, NSW 2560. c.de-matos@uws.edu.au 